\title{
THE EFFECT OF INTRAVENOUS DIAZEPAM ON RISE OF INTRAOCULAR PRESSURE FOLLOWING SUCCINYLCHOLINE
}

\author{
Anthony J. Cunningham, Odette Albert, James Cameron and A.G. Watson
}

\section{ABSTRACT}

\begin{abstract}
Because succinylcholine raises intraocular pressure, its use to facilitate tracheal intubation for ocular surgery, especially in emergency open-eye cases, has been a controversial topic among anaesthetists for more than two decades. In recent years, intravenous diazepam pretreatment before succinylcholine has been reported to reduce the untoward side effects of myalgia, and elevation of serum potassium and creatine phosphokinase. This study was designed to assess the effect of pretreatment with intravenous diazepam $0.1 \mathrm{mg} \cdot \mathrm{kg}^{-1}$ on control (base-line) intraocular pressure and to determine if such pretreatment diminished the rise in intraocular pressure following the standard anaesthesia induction sequence of thiopentone $3-5 \mathrm{mg} \cdot \mathrm{kg}^{-1}$ and succinylcholine $1 \mathrm{mg} \cdot \mathrm{kg}^{-1}$, followed by tracheal intubation. Such diazepam pretreatment was shown to reduce the intraocular pressure from control levels and to diminish the rise of intraocular pressure following succinylcholine and tracheal intubation. Because succinylcholine produces rapid onset of neuromuscular block for tracheal intubation and since only minor intraocular pressure elevation occurs following thiopentone and succinylcholine in patients pretreated with diazepam, its use in ocular surgery, including emergency open-eye cases, can be rationally advocated. The addition of $0.6 \mathrm{mg} \cdot \mathrm{kg}^{-1} \mathrm{~d}$-tubocurarine to the diazepam pretreatment did not produce a further reduction of the increase of intraocular pressure following succinylcholine.
\end{abstract}

KEY WORDS: EYE, intraocular pressure, succinylcholine, diazepam.

Published studies from as early as the mid 1950s have shown that succinylcholine, given intravenously to facilitate tracheal intubation, produces a transient but significant rise in intraocular pressure and vitreous loss has occurred following its use in the presence of an open eye. ${ }^{1}$ In a series of volunteers given succinylcholine without anaesthesia, rises in intraocular pressure of $18 \mathrm{mmHg}$ have been reported. ${ }^{2}$ Following induction of anaesthesia with thiopentone and succinylcholine, intraocular pressure increased within the first minute following succinylcholine, with a peak increase of 6-8 $\mathrm{mmHg}$ between $2-4$ minutes and returned to control values by 6 minutes. ${ }^{3}$ Tracheal intubation following succinylcholine exaggerated the rise in intraocular pressure but did not prolong it. Many techniques have been

Anthony J. Cunningham, M.B., B.CH., F.R.C.P. (C), Department of Anaesthesia; Odette Albert, M.D., Resident in Anaesthesia; James Cameron, M.D., Resident in Ophthalmology; A.G. Watson, M.D. F.R.C.S. (C) Professor and Head, Department of Ophthalmology; Ottawa Health Science Centre General Hospital, Ottawa, Ontario.

Address correspondence to Dr. A.J. Cunningham, Department of Anaesthesia, Ottawa Health Science Centre General Hospital, 501 Smyth Road, Ottawa, Ontario K1H 8L6 advocated to prevent the rise in intraocular pressure following succinylcholine administration. Carballo ${ }^{4}$ advocated the pre-operative administration of acetazolamide, a carbonic anhydrase inhibitor, while Miller $^{5}$ reported that gallamine and d-tubocurarine pretreatment prevented the subsequent rise in intraocular pressure. However, more recently Meyers, ${ }^{6}$ using the more sensitive applanation tonometry measurements, showed that neither gallamine nor d-tubocurarine pretreatment abolished the rise in intraocular pressure following succinylcholine. In 1979, Fahamy ${ }^{7}$ and Eisenberg ${ }^{8}$ separately reported the effect of pretreatment with intravenous diazepam $0.05 \mathrm{mg} \cdot \mathrm{kg}^{-1}$ in reducing succinylcholine-induced myalgia and increase of serum potassium and creatine phosphokinase.

Diazepam has been reported to decrease intraocular pressure; 9 therefore this study was undertaken to determine if pretreatment with intrave. nous diazepam $0.1 \mathrm{mg} \cdot \mathrm{kg}^{-1}$ five minutes before succinylcholine can prevent the subsequent rise in intraocular pressure during normal anaesthesia induction. In addition the effect of combined pretreatment with intravenous diazepam 0.1 $\mathrm{mg} \cdot \mathrm{kg}^{-1}$ and d-tubocurarine $0.06 \mathrm{mg} \cdot \mathrm{kg}^{-1}$ on intraocular pressure changes following succinylcholine was studied. 


\section{METHODS}

Forty-nine male and female subjects who had given informed consent and were undergoing elective minor surgical procedures were studied. The patients' ages ranged from 17- 45 years (mean age 29.3 years; $S \mathrm{E}$ I.1). All patients were A.S.A. class I or II, and had no ocular disease. No patient had renal, hepatic or neuromuscular disease, nor was any patient receiving medication known to affect myoneural transmission. They received no premedication. The patients were allocated to three treatment groups.

\section{Treatment Group I}

$(\mathrm{n}-10)$. Anaesthesia was induced with thipentone $3-5 \mathrm{mg} \cdot \mathrm{kg}^{-1}$ and succinylcholine $1 \mathrm{mg} \cdot \mathrm{kg}^{-1}$. A Professional Instruments Company NS-2A peripheral nerve stimulator was used to stimulate the ulnar nerve. The trachea was intubated when the twitch response was abolished after succinylcholine and anaesthesia was then maintained with nitrous oxide-oxygen $4: 2$ litres/min and 0.5 per cent halothane, using a Bain non-rebreathing anaesthesia circuit. Controlled ventilation was employed in all cases.

\section{Treatment Group II}

$(n-20)$. Each patient received intravenous diazepam $0.1 \mathrm{mg} \cdot \mathrm{kg}^{-1}$ five minutes before induction with thiopentone $3-5 \mathrm{mg} \cdot \mathrm{kg}^{-1}$ and succinylcholine $1 \mathrm{mg} \cdot \mathrm{kg}^{-1}$, as in treatment Group I. The subsequent conduct of anaesthesia was identical to that of Group I.

\section{Treatment Group III}

$(n-19)$. Each patient was given intravenous diazepam $0.1 \mathrm{mg} \cdot \mathrm{kg}^{-1}$ and d-tubocurarine 0.06 $\mathrm{mg} \cdot \mathrm{kg}^{-1}$ five minutes before thiopentone 3-5 $\mathrm{mg} \cdot \mathrm{kg}^{-1}$ and succinylcholine $1.5 \mathrm{mg} \cdot \mathrm{kg}^{-1}$. The subsequent conduct of anaesthesia was identical to that of Groups I and II.

Blood pressure and electrocardiogram were monitored constantly and arterial blood gas anal$y$ sis was done at the time of induction of anaesthesia to ensure normocarbia and normal $\mathrm{Pa}_{\mathrm{O}_{2}}$.

Intraocular pressure measurements were done by an ophthalmologist (J.C.) using a portable hand-held applanation tonometer, after 1-3 drops of topical tetracaine 0.5 per cent had been instilled in the patient's left eye. Measurements were made on arrival in the operating room (control value), at the time of abolition of the twitch response after succinylcholine, two min- utes after tracheal intubation and five minutes after intubation,

In addition, intraocular pressure was measured in treatment groups II and III five minutes after diazepam and after diazepam plus d-lubocurarine pretreatment, before induction of anaesthesia.

\section{Statistical Analysis}

The average control values for the three groups were examined for differences ( $F$ test). All other measurements were expressed as changes from control values, to separate the effect of drugs on intraocular pressure from patient to patient variability in base-line intraocular pressure. In treatment Groups II and III, the changes in intraocular pressure from controls to levels after diazepam, and those after diazepam plus d-tubocurarine were assessed by t-tests. These two treatment groups were also compared to see if they differed in the magnitude of change (t-test).

The patterns of the average intraocular pressure values at the other three times were then assessed using a profile analysis technique ${ }^{10}$ to determine whether the patterns of values for each treatment group were parallel, and whether they differed in level.

If an over-all difference in level was found, pairs of treatments, differing in level, were identified by calculation of Scheffé confidence limits - a very conservative technique applicable to treatment groups of unequal size.

\section{RESUltS}

Table I displays average intraocular pressure values ( $\pm S E$ ) for each treatment group, at each point of observation. Table II contains average changes from control at each point of observation $( \pm$ SE). The data of Table $I$ are displayed in Figure 1.

There did not appear to be any appreciable difference in the control intraocular pressure values for the three treatment groups $(P<.05)$.

In both groups II and III there was a significant reduction in intraocular pressure from controls to the post-diazepam reading and to that after diazepam plus $d$-tubocurarine respectively ( $P$ $<.05$ ); however the magnitude of this drop did not differ for the two groups.

Figure 2 contains a profile of the average intraocular pressure readings in each of the three treatment groups; after succinylcholine and two minutes and five minutes post-intubation. The post-diazepam and post-diazepam plus d-tubo- 
TABLE 1

Intraocular Pressure - Average Group Values \pm SE

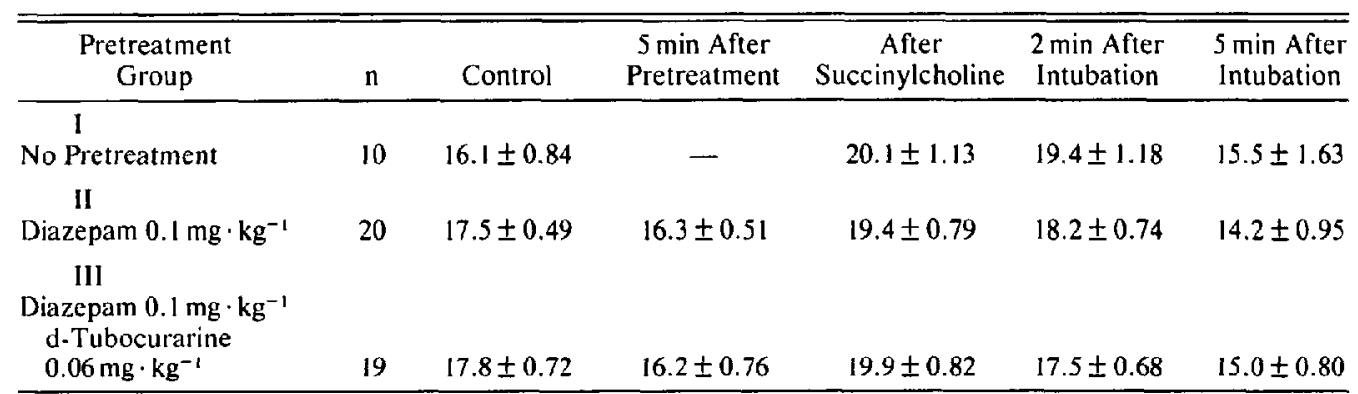

TABLE II

intraocular Pressure - Average Group Values Difference from Control \pm SE

\begin{tabular}{|c|c|c|c|c|}
\hline $\begin{array}{l}\text { Pretreatment } \\
\text { Group }\end{array}$ & $\begin{array}{c}5 \min \text { After } \\
\text { Pretreatment }\end{array}$ & $\begin{array}{c}\text { After } \\
\text { Succinylcholine }\end{array}$ & $\begin{array}{l}2 \mathrm{~min} \text { After } \\
\text { Intubation }\end{array}$ & $\begin{array}{l}5 \text { min After } \\
\text { Intubation }\end{array}$ \\
\hline I & & & & \\
\hline $\begin{array}{l}\text { No Pretreatment } \\
\text { II }\end{array}$ & - & $4.0 \pm 0.68$ & $3.3 \pm 1.0$ & $-0.6 \pm 1.68$ \\
\hline $\begin{array}{l}\text { Diazepam } 0.1 \mathrm{mg} \cdot \mathrm{kg}^{-1} \\
\text { III }\end{array}$ & $-1.15 \pm 0.44$ & $1.95 \pm 0.61$ & $0.75 \pm 0.63$ & $-3.25 \pm 0.91$ \\
\hline $\begin{array}{l}\text { Diazepam } 0.1 \mathrm{mg} \cdot \mathrm{kg}^{-1} \\
\text { d-Tubocurarine } \\
0.06 \mathrm{mg} \cdot \mathrm{kg}^{-1}\end{array}$ & $-1.68 \pm 0.56$ & $2.11 \pm 0.74$ & $-0.37 \pm 0.81$ & $-2.84 \pm 0.99$ \\
\hline
\end{tabular}

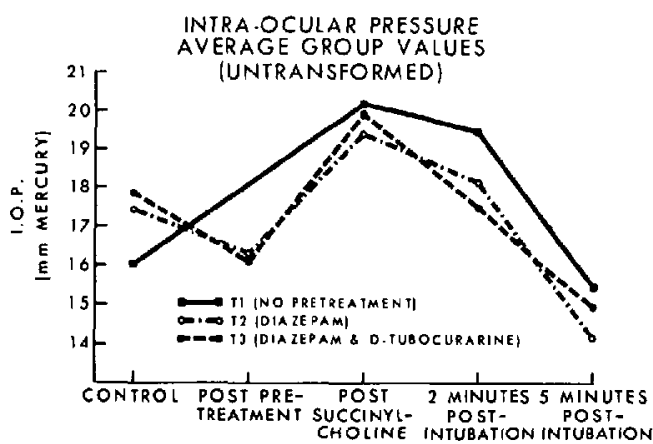

FlGURE I Average intraocular pressure $(\mathrm{mmHg})$ in controls and in each pretreatment group at indicated observation points.

curarine readings of Groups II and III are also included. All values are average of differences from control levels.

When the profiles of the three readings common to all treatment groups were assessed the following was found.

(a) The three profiles were parallel $(\mathbf{P}<.05)$ - that is, the groups had a similar pattern of response.

(b) The profiles for the group receiving diazepam (Group II), and diazepam plus d-tubocurarine (Group III), were lower than the profile for the

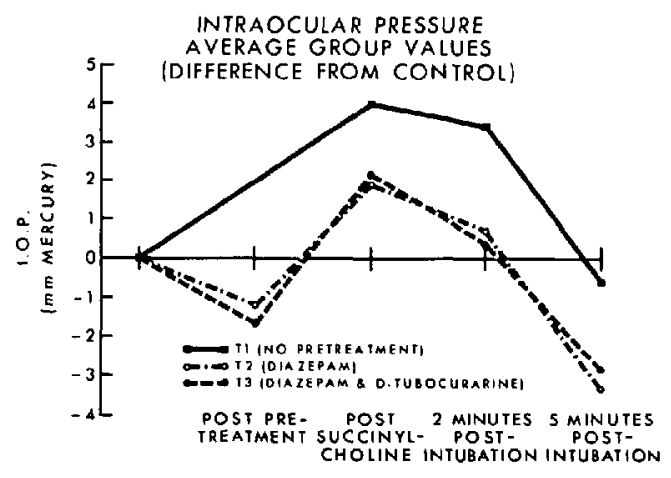

Figure 2 Difference from control of average intraocular pressure $(\mathrm{mmHg})$ in each pretreatment group at indicated observation points.

group with no pretreatment (Group I) $(\mathrm{P}<0.12)$. The levels of the profiles for the group receiving diazepam (Group II) did not differ from that receiving diazepam plus d-tubocurarine (Group III).

\section{Discussion}

This present study confirms the often reported observation that succinylcholine produces a rise in intraocular pressure and, in this study, the 
intraocular pressure rose $4 \mathrm{mmHg}$ above control following administration of thiopentone and succinylcholine. Intravenous thiopentone reduced intraocular pressure and diminished the subsequent rise caused by succinylcholine. "The anterior and posterior chambers of the eye are filled with aqueous humour, a low protein fluid. Two-thirds of the aqueous is formed in the posterior chamber by energy-dependent active secretion in the ciliary process, utilizing carbonic anhydrase. The remaining one third of the aqueous is formed by passive diffusion through the anterior surface of the iris. The volume of aqueous depends on the balance between its formation and its drainage from the anterior chamber through the canal of Schlemm to the ophthalmic vein. ${ }^{12}$ Besides the effects of succinylcholine, changes in intraocular pressure produced by anaesthetic agents ${ }^{13}$ and tracheal intubation may result from altered aqueous humour dynamics, changes in intraocular vascular volume, contraction or relaxation of the extraocular muscles, altered central nervous system activity and cardiorespiratory effects, including increased central venous pressure, arterial blood pressure, and carbon dioxide tension. ${ }^{14}$

The depolarizing relaxant succinylcholine is thought to raise intraocular pressure by producing a slow and prolonged tonic contraction of the extraocular muscles. ${ }^{15}$ Extraocular muscle differs from ordinary skeletal muscle in that it contains a specific histological structure called Felderstruktur ${ }^{16}$ which, when exposed to acetylcholine, or when immersed in depolarizing solution, responds with a slow tonic contraction. A portion of the rise in intraocular pressure following succinylcholine may result from choroidal vascular dilation and relaxation of orbital smooth muscle. Thus study demonstrates the effect of intravenous diazepam $0.1 \mathrm{mg} \cdot \mathrm{kg}^{-1}$ in reducing intraocular pressure from control levels, and when such diazepam preteatment was given intravenously five minutes before induction of anaesthesia with thiopentone and succinylcholine, followed by tracheal intubation, only minor elevation of intraocular pressure above control ensued $(1.95 \pm 0.61 \mathrm{mmHg})$. Two minutes after intubation the intraocular pressure had returned to $0.75 \pm 0.63 \mathrm{mmHg}$ above control.

The mechanism of action of diazepam in reducing intraocular pressure is uncertain, but it is postulated that it may inhibit the tonic contraction of the extraocular muscles following succinylcholine. The benzodiazepines have muscle relaxant properties, and they have been used to control muscle rigidity and spasms in patients with tetanus, cerebral palsy and trismus. ${ }^{17}$ The site of action of diazepam in probably on central supraspinal structures, the reticular facilitatory system, and on polysnaptic pathways within the spinal cord. ${ }^{18}$ The benzodiazepine drugs may facilitate the inhibitory actions of gamma-aminobutyric acid (GABA) in the cerebral cortex and motor pathways in the brain, as well as producing glycine-like effects in the spinal cord. ${ }^{19} \mathrm{~A}$ minor site of action may be the neuromuscular junction of the extraocular muscle - a presynaptic action of diazepam which might involve reduction in release or synthesis of acetylcholine..$^{20}$ In addition, diazepam, in the commercially available form, might augment the neuromuscular blockade caused by succinylcholine. ${ }^{21}$

The anaesthetic management of the patient booked for ocular surgery, especially the emergency open-eye case, has been a controversial topic among anaesthetists. Because the nondepolarizing relaxant pancuronium has been shown to reduce intraocular pressure ${ }^{22,23}$ many now advocate a barbiturate-non-depolarizing muscle relaxant induction sequence, using preoxygenation and cricoid pressure, when presented with emergency ocular surgery.

The major disadvantages of the technique are:

(1) The delayed onset of sufficient paralysis for tracheal intubation. Pancuronium, in an intravenous bolus dose as high as $0.15 \mathrm{mg} \cdot \mathrm{kg}^{-1}$ required $1.8 \pm 0.2$ minutes to achieve 95 per cent twitch suppression. ${ }^{24}$ This long interval is a major drawback to this technique while the airway is unprotected.

(2) The danger of coughing and straining during intubation: by rapidly increasing the venous pressure a cough can raise the intraocular pressure by $34-40 \mathrm{mmHg} .^{25}$

(3) The prolonged duration of neuromuscular blockade: with an intravenous bolus of pancuronium $0.15 \mathrm{mg} \cdot \mathrm{kg}^{-1}$ (a $10.5 \mathrm{mg}$ dose for a $70 \mathrm{~kg}$ adult) the time interval from injection to 25 per cent return of twitch height was $159 \pm 18$ minutes. ${ }^{24}$ The prolonged duration of neuromuscular blockade resulting from such doses of pancuronium may necessitate postoperative mechanical ventilatory support. In one series, ${ }^{26}$ one out of ten patients receiving pancuronium $0.15 \mathrm{mg} \cdot \mathrm{kg}^{-1}$ and seven out of ten patients, receiving $0.2 \mathrm{mg} \cdot \mathrm{kg}^{-1}$ required postoperative ventilation after surgical procedures of unspecified duration. 
In comparison with pancuronium, succinylcholine offers the advantages of rapid onset of relaxation (the time interval from bolus administration of $1 \mathrm{mg} \cdot \mathrm{kg}^{-1}$ succinylcholine to abolition of twitch response is $63 \pm 5.1$ seconds), ${ }^{27}$ smooth intubating conditions and short duration of action.

Since an intravenous bolus of succinylcholine $1 \mathrm{mg} \cdot \mathrm{kg}^{-1}$ produces such minor changes in intraocular pressure, when given following thiopentone $3-5 \mathrm{mg} \cdot \mathrm{kg}^{-1}$ in patients pretreated with diazepam, its use is justified in ocular surgery, including emergency open-eye cases. A review of 2,217 cataract operations under general anaesthesia, using succinylcholine as the muscle relaxant, showed no major differences in intraoperative and post-operative complications compared to local anaesthesia. ${ }^{28}$ An interesting footnote is the failure of the addition of d-tubocurarine $0.6 \mathrm{mg} \cdot \mathrm{kg}^{-1}$ to the diazepam $0.1 \mathrm{mg} \cdot \mathrm{kg}^{-1}$ pre-treatment to produce a further reduction in intraocular pressure following succinylcholine.

\section{ACKNOWLEDGEMENTS}

The authors wish to acknowledge the valuable assistance of Mrs. Georgia Roberts M.Sc., who did the statistical analyses and Mrs. France Greenwood, who provided secretarial services.

\section{REFERENCES}

1. Lincoff, H.A., Ellis, C.H., De Voe, A.G. et al. The effect of succinylcholine of intraocular pressure. Am. J. Ophthalmol. 40: 501-510 (1955).

2. Hoffman, H. \& Holzer, H. Die Wirkung von Muskelrelaxantien auf den intraokularen Druck. Klin Monatsbl Augenheilk 123: 1-16 (1953).

3. Pandey, K., Badola, R.P. \& Kumar, S. Time course of intraocular hypertension produced by suxamethonium. Brit. J. Anaesth. 44: 191-195 (1972).

4. Carballo, A.S. Succinylcholine and acetazolamide (Diamox) in anaesthesia for ocular surgery. Can. Anaes. Soc. J, 12: 486 (1965).

5. MILleR, R.D., WAY, W.L.\& HickeY, R.F. Inhibition of succinylcholine-induced intraocular pressure by nondepolarizing muscle relaxants. Anesthesiology 29, 123-126 (1968).

6. Meyers, E.F., KRupin, T., Johnson, M. \& Zinc, $\mathrm{H}$. Failure of nondepolarizing neuromuscular blockers to inhibit succinylcholine-induced increased intraocular pressure; a control study. Anesthesiology 48: 149-151 (1978).

7. FaHMY, N.R., Malek, N.S. \& LaPPas, D.G. Diazepam prevents some adverse effects of succinylcholine. Clin. Pharmacol. Ther. 26: 395-398 (1979).
8. Eisenberg, N., Balsley, S. \& Katz, R.L. Effect of diazepam, on succinylcholine-induced myalgia, potassium increase, creatine phosphokinase elevation and relaxation. Anesth. Analg. 58: 314-317 (1979).

9. AL-ABRAK, M.H. Diazepam and intraocular pressure. Br. J. Anaesth. 50: 866 (1978).

10. Morrison, D.F. Multivariate Statistical Methods. 1st ed., Toronto, McGraw Hill Book Company (1967).

11. Chandraskekhar, J. \& Bruce, D.L. Thiopental and succinylcholine: Action on intraocular pressure. Anesth. and Analg. 54: 471-475 (1975).

12. Anesthesia in Ophthalmology: International Ophthalmology Clinics. R.B. SMITH (Ed.) Boston, Little, Brown. (Aboul-Eish, E.: Physiology of the eye pertinent to anesthesia, vol. 13: 1-18 (1973).

13. SELF, W.G. \& Elcis P.P. The effects of general anesthetic agents on intraocular pressure. Survey of Ophthalmology 21: 494-499 (1977).

14. Dunclaf, D. \& Waitzner, S.W. The influence of ventilation and hypercapnia on intraocular pressure during anesthesia. Anesth. Analg. (Cleve) 42: 232-237, (1963).

15. Dillon, J.B., Sabawala, P. \& Taylor, D.B. Depolarizing neuromuscular blocking agents and intraocular pressure in vivo. Anesthesiology 18: 439-442 (1957).

16. Miller, J.E. Cellular organization of rhesus extraocular muscle. Invest. Ophthalmolg. 6: 18-39 (1967).

17. Dundee, J.W. \& Haslet, W.H.K. The benzodiazepine. Brit. J. Anaesth. 42: 217-234 (1970).

18. NGaI, S.H., Tseng, D.T.C. \& WANG, S.C. Effects of diazepam and other central nervous system depressants on spinal reflexes in cats. A study of site of action. J. Pharmacol. Exp. Ther. 153: 244-351 (1966).

19. Richter. J.J. Current theories about the mechanism of benzodiazepines and neuroleptic drugs. Anesthesiology 54:66-72 (1981).

20. Feldam, S.A. \& Crawley, B.E. Interaction of diazepam with the muscle-relaxant drugs. Brit. Med. J. 2: 336-338 (1970).

21. Sharma, K.K. \& Sharma, U.C. The influence of diazepam on the effect of neuromuscular blocking agents. J. Pharm. Pharmac. 30: 64 (1978).

22. Hitwiller, R.W., Difazio, C.A. \& Rushia, E.L. Pancuronium and intraocular pressure. Anesthesiology 42: 750-752 (1975).

23. Patenaude, B.L.. Robblee, J.A. \& Watson, A.G. The value of pancuronium in prolonged intraocular operations. Canad. J. Ophthal. $12: 265$ (1977).

24. Lebowitz, P.W., Frederic, R.M., Savarese, J.J., ALI, H.H. \& DEBros, F.M. Combination of pancuronium and metocurine: Neuromuscular and hemodynamic advantages over pancuronium alone. Anesth. Analg. 60: 12-17 (1981).

25. MACRI, F.J. Vascular pressure relationship and intraocular pressure. Arch. Ophthalmol. 65: 571 (1961).

26. Brown, E.M., Krishnaprasad \& Smiler, B. Pancuronium for rapid induction technique for tracheal intubation. Can. Anaesth. Soc. J. 26: 489-491 (1979). 
27. Cullen, D.J. The effect of pretreatment with nondepolarizing muscle relaxants on the neuromuscular blocking action of succinylcholine. Anesthesiology 35: 572-578 (1971).
28. LynCh, S., Wolf, G.L. \& Berlin, I. General anesthesia for cataract surgery: A comparative review of 2,217 consecutive cases. Anesth. and Analg. 53: 909-913 (1974).

\section{RÉSUMÉ}

A cause de son pouvoir d'augmenter la tension intraoculaire, l'usage de la succinylcholine en chirurgie oculaire et plus spécialement dans les traumatismes ouverts a été le sujet de vives controverses parmi les anesthésistes pendant les deux dernières décades. Récemment, on a rapporté que le prétraitement par la voie veineuse au diazepam annulait certains effets sccondaires du diazepam comme la myalgie, l'élévation du potassium sérique et de la créatine phosphokynase. La présente étude a été entreprise dans le but d'évaluer l'effet du prétraitement au diazepam à la dose de $0.1 \mathrm{mg} \cdot \mathrm{kg}^{-1}$ sur la pression intraoculaire de contrôle initiale et de déterminer si ce traitement pouvait faire décroitre l'augmentation de pression intraoculaire consécutive à une induction standard thiopentone sodium 3 à $5 \mathrm{mg} \cdot \mathrm{kg}^{-1}$ avec association de succinylcholine $1 \mathrm{mg} \cdot \mathrm{kg}^{-1}$ suivie de l'intubation de la trachée. Le traitement au diazepam a effectivement abaissé la pression intraoculaire de contrôle et diminué l'augmentation de pression oculaire consécutive à l'injection de succinylcholine et à l'intubation de la trachée. Comme la succinylcholine cause un blocage neuromusculaire rapide qui facilite l'intubation de la trachée et comme l'augmentation de la pression intraoculaire devient négligeable après la succinylcholine et l'intubation, si on administre préablement une dose de diazepam appropriée, son emploi en chirurgie oculaire incluant la chirurgie d'urgence pour traumatisme ouvert, peut ètre rationnel. L'addition de tubocurarine $0.06 \mathrm{mg} \cdot \mathrm{kg}^{-1}$ au prétraitement du diazepam n'a pas produit de réduction supplémentaire de la pression intraoculaire causée par la succinylcholine. 